\title{
A new source of oxygenated organic aerosol and oligomers
}

\author{
J. Liggio and S.-M. Li \\ Air Quality Processes Research Section, Environment Canada, 4905 Dufferin Street, Toronto, Ontario M3H 5T4, Canada \\ Correspondence to: J. Liggio (john.liggio@ec.gc.ca)
}

Received: 31 October 2012 - Published in Atmos. Chem. Phys. Discuss.: 12 November 2012

Revised: 14 February 2013 - Accepted: 1 March 2013 - Published: 15 March 2013

\begin{abstract}
A large oxygenated organic uptake to aerosols was observed when exposing ambient urban air to inorganic acidic and non-acidic sulfate seed aerosol. For non-acidic seed aerosol the uptake was attributed to the direct dissolution of primary vehicle exhaust gases into the aqueous aerosol fraction, and was correlated to the initial seed sulphate mass. The uptake of primary oxygenated organic gases to aerosols in this study represents a significant amount of organic aerosol (OA) that may be considered primary when compared to that reported for primary organic aerosol (POA), but is considerably more oxygenated $(\mathrm{O}: \mathrm{C} \sim 0.3)$ than traditional POA. Consequently, a fraction of measured ambient oxygenated OA, which correlates with secondary sulphate, may in fact be of a primary, rather than secondary source. These results represent a new source of oxygenated OA on neutral aerosol and imply that the uptake of primary organic gases will occur in the ambient atmosphere, under dilute conditions, and in the presence of pre-existing $\mathrm{SO}_{4}$ aerosols which contain water. Conversely, under acidic seed aerosol conditions, oligomer formation was observed with the uptake of organics being enhanced by a factor of three or more compared to neutral aerosols, and in less than $2 \mathrm{~min}$, representing an additional source of SOA to the atmosphere. This resulted in a trajectory in Van Krevelen space towards higher $\mathrm{O}: \mathrm{C}$ (slope $\sim-1.5$ ), despite a lack of continual gas-phase oxidation in this closed system. The results demonstrate that high molecular weight species will form on acidic aerosols at the ambient level and mixture of organic gases, but are otherwise unaffected by subsequent aerosol neutralization, and that aerosol acidity will affect the organic $\mathrm{O}: \mathrm{C}$ via aerosolphase reactions. These two processes, forming oxygenated POA under neutral conditions and SOA under acidic conditions can contribute to the total ambient $\mathrm{OA}$ mass and the evolution of ambient aerosol $\mathrm{O}: \mathrm{C}$ ratios. This may be im-
\end{abstract}

portant for properly representing organic aerosol $\mathrm{O}: \mathrm{C}$ ratios in air quality and climate models.

\section{Introduction}

Despite the recognized importance of organic aerosol (OA), its varied sources remain only partially understood. Broadly $\mathrm{OA}$ can be divided into primary organic aerosol (POA) or secondary organic aerosol (SOA). The relative importance of SOA and POA to total OA has been the focus of numerous studies. Typically, SOA dominates the OA mass (Zhang et al., 2007; Jimenez et al., 2009), yet its formation mechanisms remain uncertain. This is demonstrated by the fact that traditional oxidation mechanisms (via $\mathrm{OH}, \mathrm{O}_{3}$ and $\mathrm{NO}_{3}$ ) are unable to account for SOA observations (Volkamer et al., 2006; Zhang and Ying, 2011). Oligomer formation via aerosol-phase chemistry is of potential importance to overall SOA formation (Nguyen et al., 2011; Hall IV and Johnston, 2011), as is the formation of semi-solid particles which affects gas-particle partitioning (Vaden et al., 2011; Perraud et al., 2012). Neither of these two processes are adequately parameterized in models but may help to explain discrepancies between models and observations.

Precursor VOC oxidation leads to products with a higher oxygen content and lower saturation vapor pressures, thus enabling the products to partition to aerosols. Hence, the degree of oxygenation in OA, represented by the $\mathrm{O}: \mathrm{C}$ ratio, has been used to infer source types (POA vs. SOA) (Liggio et al., 2010; Sun et al., 2011), and is related to aerosol properties such as volatility and hygroscopicity (Jimenez et al., 2009; Murphy et al., 2011; Huffman et al., 2009). High O : C ratios in OA have been linked to SOA and oxidative aging (Jimenez et al., 2009); conversely, low O:C indicate POA (Aiken et 
al., 2008; Chirico et al., 2010). In addition, the relationship between the $\mathrm{H}: \mathrm{C}$ and $\mathrm{O}: \mathrm{C}$ ratios has been used to describe organic functional group evolution and aging from field and laboratory experiments (Tkacik et al., 2012; Lambe et al., 2012; Heald et al., 2010; Ng et al., 2011a; Kroll et al., 2011). Those results show that a continual evolution of OA to higher $\mathrm{O}: \mathrm{C}$ ratios will occur under oxidative conditions leading to more highly oxidized functional groups in the OA. Understanding the processes which alter organic aerosol mass and $\mathrm{O}: \mathrm{C}$ is thus critical to modeling aerosol properties and ultimately their effect on climate.

Recent laboratory studies have shown that the direct condensational uptake of vehicle exhaust gases to neutral sulfate aerosols (S.-M. Li et al., 2011) can increase OA mass in those experiments. If the uptake involves primary oxygenated species as hypothesized, then it may lead to changes in the degree of aerosol oxygenation if significant OA mass is added under ambient dilute exhaust conditions. Such a process occurring on short time and spatial scales could lead to oxygenated OA mass which will be indistinguishable from SOA, implying that POA may be more oxygenated than previously considered.

Furthermore, aerosol-phase chemistry leading to high MW species and oligomers has been shown to be a potentially important pathway to OA (Hall IV and Johnston, 2011), yet the role of aerosol acidity in oligomer formation remains uncertain. While some studies have noted enhanced oligomer mass under acidic aerosol conditions (Denkenberger et al., 2007; Gao et al., 2004), others have observed an insignificant effect (Zhang et al., 2012). Additionally, many smog chamber experiments are performed utilizing single gaseous organic species at high concentrations, and/or very high initial seed mass loading. These conditions may not be entirely representative of the ambient atmosphere, and hence the importance of the above processes under dilute ambient conditions, where a multitude of species simultaneously exist, remains somewhat unclear, as does its effect on the oxygen content of the resultant aerosols.

In the present study, the partitioning and reactive uptake of the ambient mixture and concentration of gases to aerosols is investigated by exposing urban ambient air to sulphate aerosols. The results demonstrate that the condensation of existing ambient primary species will lead to significant oxygenated OA on neutral particles, prior to gas-phase oxidation. The uptake of ambient gaseous organics to acidic aerosol and subsequent aerosol-phase chemistry will also result in high MW species and/or oligomers which significantly enhance aerosol oxygenation. The implications of this new route to oxygenated $\mathrm{OA}$ to the overall aerosol mass and oxygenation levels are discussed.

\section{Methods}

Experiments were performed in a $2 \mathrm{~m}^{3}$ Teflon chamber in the dark by exposing aerosol filtered, urban ambient air to sulphuric acid aerosols and ammonia. Details of the experimental procedure have been given elsewhere (Liggio et al., 2011) and initial experimental conditions are given in Table 1. Experiments were conducted by filling the chamber with particle filtered ambient air over several hours, followed by the formation of sulphuric acid aerosols in the chamber in 2$20 \mathrm{~s}$ via the reaction of added $\mathrm{SO}_{3}$ and ambient water vapour (Chan and Mozurkewich, 2001; Baker et al., 1999). The ambient aerosols were filtered with a $47 \mathrm{~mm}$ Teflon filter at a flow rate of approximately $15 \mathrm{~L} \mathrm{~min}^{-1}$. The initially generated sulphate loadings spanned the range of $2.7-28 \mu \mathrm{g} \mathrm{m}^{-3}$, at a relative humidity (RH) of $40-50 \%$. Ammonia $\left(\mathrm{NH}_{3}\right)$ was always present (or added) in the chamber prior to $\mathrm{SO}_{3}$ addition, at levels that ranged from $\sim 1-43$ ppbv. Low $\mathrm{NH}_{3}$ levels $(<5$ ppbv) were present in the ambient air for some experiments. Higher concentrations were achieved by addition and dilution of high purity $\mathrm{NH}_{3}(10 \mathrm{ppm}$, Scott specialty) prior to the introduction of acidic aerosols. The reaction between ammonia $\left(\mathrm{NH}_{3}\right)$ and $\mathrm{H}_{2} \mathrm{SO}_{4}$ aerosols resulted in acidic or neutral seed aerosols depending upon the concentration of pre-existing ammonia. Control experiments were performed by using organic-free zero air (Table 1) in place of ambient air.

Aerosol size and number were characterized with a Scanning Mobility Particle Sizer (SMPS, TSI Inc.), with a scan time of $3 \mathrm{~min}$. Aerosol inorganic and organic masses were quantified with a high resolution time-offlight aerosol mass spectrometer (HR-ToF-AMS, Aerodyne Research Inc) (DeCarlo et al., 2006). AMS elemental analysis was accomplished using APES 1.04 integrated into PIKA v1.07 (http://cires.colorado.edu/jimenez-group/ ToFAMSResources/ToFSoftware/index.html) (Aiken et al., 2007, 2008). The AMS collection efficiency (CE) in this study was determined by comparing SMPS derived mass with the AMS derived mass, and ranged from 22-100\%, in accord with the results of Matthew et al. (2008) for the types of aerosols studied here. Regardless, the CE did not affect the results of this study, as organics and sulphate were internally mixed and the organic uptake was normalized by the latter. Ambient aerosols up-stream of the Teflon filter were also measured with the HR-ToF-AMS for 10-60 min prior to introduction of the sulphate aerosol. Organic gases in the chamber were measured with a high resolution time-offlight proton transfer reaction mass spectrometer (HR-ToFPTR-MS) (Jordan et al., 2009). The PTR-ToF-MS measures a subset of VOCs including oxygenated, aromatic and olefin species. The local ambient VOCs found during this study were a mixture of those from aged regional air, biogenic emissions and a major roadway $\sim 100 \mathrm{~m}$ away with predominantly gasoline light duty vehicle traffic. The calibrated concentrations of selected species during these experiments were 
Table 1. Initial experimental and ambient parameters.

\begin{tabular}{|c|c|c|c|c|c|c|c|}
\hline Exp. $^{a}$ & $\begin{array}{c}\mathrm{SO}_{4}^{2-} \\
\left(\mu \mathrm{g} \mathrm{m}^{-3}\right)^{\mathrm{b}}\end{array}$ & $\begin{array}{l}\mathrm{NH}_{3}(\mathrm{~g}) \\
(\mathrm{ppbv})^{\mathrm{c}}\end{array}$ & $\left(\mathrm{NH}_{3} / \mathrm{SO}_{4}\right)_{i}^{\mathrm{d}}$ & $\begin{array}{l}\text { Mode Diam. } \\
\text { (nm) }\end{array}$ & $\begin{array}{l}\text { Tol/Benz } \\
(\mathrm{ppb})^{\mathrm{e}}\end{array}$ & $\begin{array}{l}\text { Terp/Isop } \\
(\mathrm{ppb})^{\mathrm{e}}\end{array}$ & $\begin{array}{l}\text { Additional }\left[\mathrm{NH}_{3}\right] \\
\text { Pulse }(\mathrm{ppb})^{\mathrm{f}}\end{array}$ \\
\hline B1 & 11.0 & 16.7 & 6.0 & 113 & BDL & BDL & - \\
\hline B2 & 28.4 & 28.6 & 4.0 & 168 & BDL & BDL & - \\
\hline B3 & 6.8 & 153 & 89.2 & 117 & BDL & BDL & - \\
\hline E1 & 5.8 & 1.1 & 0.75 & 238 & $0.27 / 0.18$ & $0.12 / 0.57$ & - \\
\hline E2 & 15.3 & 2.3 & 0.6 & 108 & $1.0 / 0.43$ & $0.25 / 0.80$ & - \\
\hline E3 & 16.5 & 3.8 & 0.9 & 112 & $0.83 / 0.37$ & $0.23 / 0.82$ & 10.1 \\
\hline E4 & 22.0 & 26.0 & 4.7 & 200 & $2.8 / 0.83$ & $0.45 / 1.3$ & 69.8 \\
\hline E5 & 5.8 & 2.7 & 1.9 & 82 & $0.76 / 0.32$ & $0.20 / 0.48$ & 50.2 \\
\hline E6 & 6.8 & 10.5 & 6.1 & 187 & $0.81 / 0.44$ & $0.21 / 1.0$ & - \\
\hline E7 & 2.7 & 9.0 & 13.2 & 117 & $1.4 / 0.6$ & $0.41 / 0.79$ & - \\
\hline E8 & 8.9 & 11.6 & 5.2 & 155 & $2.2 / 0.63$ & $0.27 / 0.78$ & - \\
\hline E9 & 9.1 & 9.6 & 4.2 & 151 & $0.72 / 0.27$ & $0.25 / 1.3$ & - \\
\hline E10 & 5.8 & 8.8 & 6.1 & 125 & $0.57 / 0.31$ & $0.26 / 0.55$ & - \\
\hline E11 & 9.9 & 22.5 & 9.0 & 190 & $0.54 / 0.28$ & $0.27 / 0.48$ & - \\
\hline E12 & 17.0 & 43.3 & 10.1 & 115 & $2.0 / 0.34$ & $0.37 / 0.52$ & - \\
\hline E13 & 11.4 & 24.0 & 8.4 & 123 & NA & NA & - \\
\hline E14 & 20.0 & 10.0 & 2.0 & 252 & NA & NA & 71.0 \\
\hline
\end{tabular}

${ }^{\mathrm{a}}$ B1-B3 refers to background experiments with zero air but with added ammonia. ${ }^{\mathrm{b}}$ Initial CE corrected sulfate loading at $t \sim 3$ min. ${ }^{\mathrm{c}}$ Initial concentration prior to addition of $\mathrm{H}_{2} \mathrm{SO}_{4}$. ${ }^{\mathrm{d}}$ Initial molar ratio; a value of 2.0 indicates that particles should be neutral at the end of experiment. Estimated uncertainty in $\mathrm{NH}_{4} / \mathrm{SO}_{4}$ is approximately $25 \%$. ${ }^{\mathrm{e}}$ Ambient concentrations in chamber 5 min prior to $\mathrm{H}_{2} \mathrm{SO}_{4}$ addition. Tol $=$ toluene (mean: $1.1 \mathrm{ppb}), \mathrm{Benz}=$ benzene $($ mean: $0.4 \mathrm{ppb}$ ), terp $=$ terpenes (mean: $0.27 \mathrm{ppb}$ ), Isop $=$ Isoprene $(\mathrm{mean}: 0.79 \mathrm{ppb}), \mathrm{BDL}=\mathrm{below}$ detection limit. ${ }^{\mathrm{f}}$ Increase in $\mathrm{NH}_{3}$ concentration during an additional pulse of $\mathrm{NH}_{3}$ for selected experiments. Bolded experiment numbers represent slightly acidic experiments.

representative of urban and biogenic emissions and are given in Table 1. Ammonia was measured with a modified chemiluminescence instrument (Thermo Scientific, 42C). The modified chemiluminescence instrument (Thermo Scientific, 42C) measured $\mathrm{NH}_{3}$ every $10 \mathrm{~s}$ with a detection limit of approximately 500 pptv. During four experiments additional $\mathrm{NH}_{3}$ (10-70 ppb) was added to the chamber after several hours and in a short pulse $(<5 \mathrm{~s}$; Table 1$)$ to study the organic uptake reversibility with respect to aerosol neutralization.

\section{Results and discussion}

Results for ambient (E1-E14) and control (B1-B3) experiments are given in Table 2. Exposure of generated $\mathrm{H}_{2} \mathrm{SO}_{4}$ particles to organic free air and excess gaseous $\mathrm{NH}_{3}$ resulted in immediate aerosol neutralization and no measurable organic uptake $\left(0.03 \pm 0.03 \mu \mathrm{g} \mathrm{m}^{-3}\right)$. In contrast, experiments with ambient air (E1-E14) resulted in $0.1-2.5 \mu \mathrm{g} \mathrm{m}^{-3}$ of organic mass taken up on the seed aerosols $\left(2.7-22 \mu \mathrm{g} \mathrm{m}^{-3}\right.$ $\mathrm{SO}_{4}^{2-}$ seed) in the first $2 \mathrm{~min}$ and much faster than could be measured with the AMS. These ambient exposure experiments can be separated into three groups based upon their final $\left[\mathrm{NH}_{4} / \mathrm{SO}_{4}\right]$ (Table 2); those which begin with sufficient $\mathrm{NH}_{3}(\mathrm{~g})$ in the chamber initially to immediately and fully neutralize the aerosols as indicated by the final molar neutralization ratio $\left(\left[\mathrm{NH}_{4} / \mathrm{SO}_{4}\right]_{\mathrm{f}} \approx 2\right.$, E5-E7, E9-
E13); those in which the aerosols remained highly acidic $\left(\left[\mathrm{NH}_{4} / \mathrm{SO}_{4}\right]_{\mathrm{f}}<1\right.$; E1-E3); and those experiments which are slightly acidic $\left(1.5<\left[\mathrm{NH}_{4} / \mathrm{SO}_{4}\right]_{\mathrm{f}}<2 ; \mathrm{E} 4, \mathrm{E} 8, \mathrm{E} 14\right)$. An approximately $25 \%$ uncertainty in determining $\left[\mathrm{NH}_{4} / \mathrm{SO}_{4}\right]_{\mathrm{f}}$ is assumed. In some experiments particles remain slightly acidic despite an excess of $\mathrm{NH}_{3}$, consistent with a reduced $\mathrm{NH}_{3}$ uptake in the presence of organics as demonstrated in Liggio et al. (2011). A time series of the measured aerosol organic mass (normalized by sulphate to remove the effect of aerosol wall losses) for experiments within these groups is given in Fig. 1a and b. These three scenarios are discussed further below.

\subsection{Oxygenated organic uptake on non-acidic seed}

There is an initial aerosol organic mass increase $\left(\mathrm{Org} / \mathrm{SO}_{4}\right)$ for these experiments (and all other experiments) in the first $2 \mathrm{~min}$. This increase in $\mathrm{Org} / \mathrm{SO}_{4}$ occurred faster than the AMS measurement time resolution $(2 \mathrm{~min})$ for non-acidic aerosols in particular (but also slightly acidic aerosols) after which the $\mathrm{Org} / \mathrm{SO}_{4}$ remained approximately constant (Fig. 1a). This initial organic mass added is plotted as a function of the initial $\mathrm{SO}_{4}^{2-}$ seed mass in Fig. 2a. According to Fig. 2a, the mass of organics taken up is proportional to the mass of sulphate seed, particularly for those experiments with neutral particles, and those which are only slightly acidic $\left(1.5<\left[\mathrm{NH}_{4} / \mathrm{SO}_{4}\right]_{\mathrm{f}}<2\right)$. Since the integrated 
Table 2. Results of organic uptake.

\begin{tabular}{|c|c|c|c|c|c|c|}
\hline Exp. & $\begin{array}{c}\text { Org. } \\
\left(\mu \mathrm{g} \mathrm{m}^{-3}\right)^{\mathrm{a}}\end{array}$ & $\left(\mathrm{NH}_{4} / \mathrm{SO}_{4}\right)_{\mathrm{f}}^{\mathrm{b}}$ & $\begin{array}{l}\text { Ambient Org } \\
\left(\mu \mathrm{g} \mathrm{m}^{-3}\right)^{\mathrm{c}}\end{array}$ & $\mathrm{Org} / \mathrm{SO}_{4}^{\mathrm{b}}$ & $\begin{array}{c}\mathrm{O}: \mathrm{C} \\
\left(_{(\text {ambient })^{\mathrm{c}}}\right.\end{array}$ & $\begin{array}{c}\mathrm{O}: \mathrm{C} \\
(\exp )^{\mathrm{b}}\end{array}$ \\
\hline$B 1$ & $0.03 \pm 0.02$ & 2 & - & - & - & - \\
\hline B2 & $0.03 \pm 0.02$ & 2 & - & - & - & - \\
\hline B3 & $0.03 \pm 0.02$ & 2 & - & - & - & - \\
\hline E1 & 0.95 & 0.3 & 0.38 & 0.75 & 0.55 & 0.29 \\
\hline E2 & 2.5 & 0.5 & 0.6 & 0.55 & 0.50 & 0.28 \\
\hline E3 & 2.1 & $0.6^{\mathrm{d}}$ & 1.04 & 0.25 & 0.47 & 0.27 \\
\hline E4 & 1.51 & $1.5^{\mathrm{d}}$ & 1.3 & 0.07 & 0.42 & 0.17 \\
\hline E5 & 0.65 & $1.75^{\mathrm{d}}$ & 0.53 & 0.17 & 0.36 & 0.25 \\
\hline E6 & 0.4 & 1.8 & 1.6 & 0.04 & 0.51 & 0.26 \\
\hline E7 & 0.1 & 1.9 & 0.62 & 0.1 & 0.35 & 0.28 \\
\hline E8 & 0.5 & 1.7 & 1.7 & 0.1 & 0.38 & 0.30 \\
\hline E9 & 0.77 & 1.8 & 0.66 & 0.09 & 0.40 & 0.27 \\
\hline E10 & 0.2 & 2 & 0.76 & 0.14 & 0.36 & 0.32 \\
\hline E11 & 0.51 & 1.9 & 0.62 & 0.04 & 0.37 & 0.21 \\
\hline E12 & 0.11 & 2 & 0.7 & 0.03 & 0.36 & 0.30 \\
\hline E13 & 0.32 & 2 & - & 0.04 & - & 0.31 \\
\hline E14 & 1.95 & $1.5^{\mathrm{d}}$ & 0.8 & 0.15 & 0.44 & 0.24 \\
\hline
\end{tabular}

${ }^{\mathrm{a}}$ Initial organics ( $\left.2 \mathrm{~min}\right){ }^{\mathrm{b}}$ At end of experiment. Estimated uncertainty in $\mathrm{NH}_{4} / \mathrm{SO}_{4}$ is approximately $25 \%$.

${ }^{\mathrm{c}}$ Non-filtered ambient air value averaged for 10 min prior to experiment. ${ }^{\mathrm{d}}$ Prior to additional pulse of $\mathrm{NH}_{3}$. Bolded

experiment numbers represent slightly acidic experiments (E4, E8, E14).

surface area in these experiments also increases with increasing $\mathrm{SO}_{4}$ seed mass, it is difficult to deduce if the initial uptake of gases is volume or surface area dependent. However, a mass dependence in Fig. $2 \mathrm{a}$ is consistent with the results of S.-M. Li et al. (2011). In that study, organic gases from a single gasoline engine were exposed to mono-dispersed, nonacidic $\left(\mathrm{NH}_{4}\right)_{2} \mathrm{SO}_{4}$ seed aerosols, and the fast organic uptake was found to be due to the dissolution of gaseous species (i.e. seed aerosol mass dependent). The organic to sulphate ratio in those studies was shown to be related to the organic vapor pressures, and was approximately $5 \%$, (Fig. 2a) which is in good agreement with the current study $(\sim 7 \%)$.

The AMS organic mass spectrum from S.-M. Li et al. (2011) and an average organic spectrum for the first $2 \mathrm{~min}$ in the present study are shown in Fig. 2b. To be consistent with the neutral seed particles utilized in S.-M. Li et al. (2011), only experiments considered fully neutral (E5E7, E9-E13) in the present study are used in computing the average spectra. However, even slightly acidic spectra (E4, $\mathrm{E} 8$, and E14) have initial organic spectra similar to that of Fig. 2b. The two spectra (each normalized to the total signal) are remarkably similar, with a high degree of correlation $\left(R^{2}=0.90\right.$, Slope $\left.=0.9\right)$. This is not only true for the fragments which contribute to the majority of the mass (i.e. $m / z 27,41,43,44,55,67,69)$ but also many of the less prevalent fragments. Removing the contribution of the dominant fragments in the spectra (ie: $m / z 27,41,44,55$ ) does not significantly degrade the overall correlation $\left(R^{2}=0.88\right)$.
The spectra for the condensed organics on neutral aerosols in this study were also compared with those of other sources (Fig. 3). The results of Fig. 3 indicate that the added organics in this study are vastly different than those from primary organic aerosol (POA) generated from a gasoline vehicle (Mohr et al., 2009) $\left(R^{2}=0.45\right.$, Slope $\left.=0.65\right)$ despite the fact that gasoline exhaust vapours were likely the largest contributors to the initial uptake. The spectra from this study are also significantly different than the spectra derived from positive matrix factorization (PMF) used to deconvolve ambient aerosol sources and/or processes ( $\mathrm{Ng}$ et al., 2011b) (Fig. 3); particularly those of HOA (a surrogate for POA) $\left(R^{2}=0.57\right.$, Slope $=0.66$ ), semi-volatile SOA (SVOOA; $R^{2}=0.66$, Slope $=0.57$ ) or more aged, low-volatility SOA (LV-OOA; $R^{2}=0.47$, Slope $\left.=0.84\right)$.

The results of Figs. 2 and 3 most importantly demonstrate that the majority of organics taken up from ambient air likely arose from the condensation of gasoline vehicle emissions (under neutral conditions), and that the concentrations of these vapors were not significantly different than those present in the diluted engine exhaust studies of S.-M. Li et al. (2011). These results are consistent with gasoline engine exhaust being the dominant source of VOCs/SVOCs during the present study, as shown by the relatively high benzene and toluene concentrations in the ambient air (Table 1) and the close proximity to a major roadway $(<100 \mathrm{~m})$. Furthermore, the ratio of toluene to benzene in the chamber during these experiments was approximately 3.0 (mean), which is 

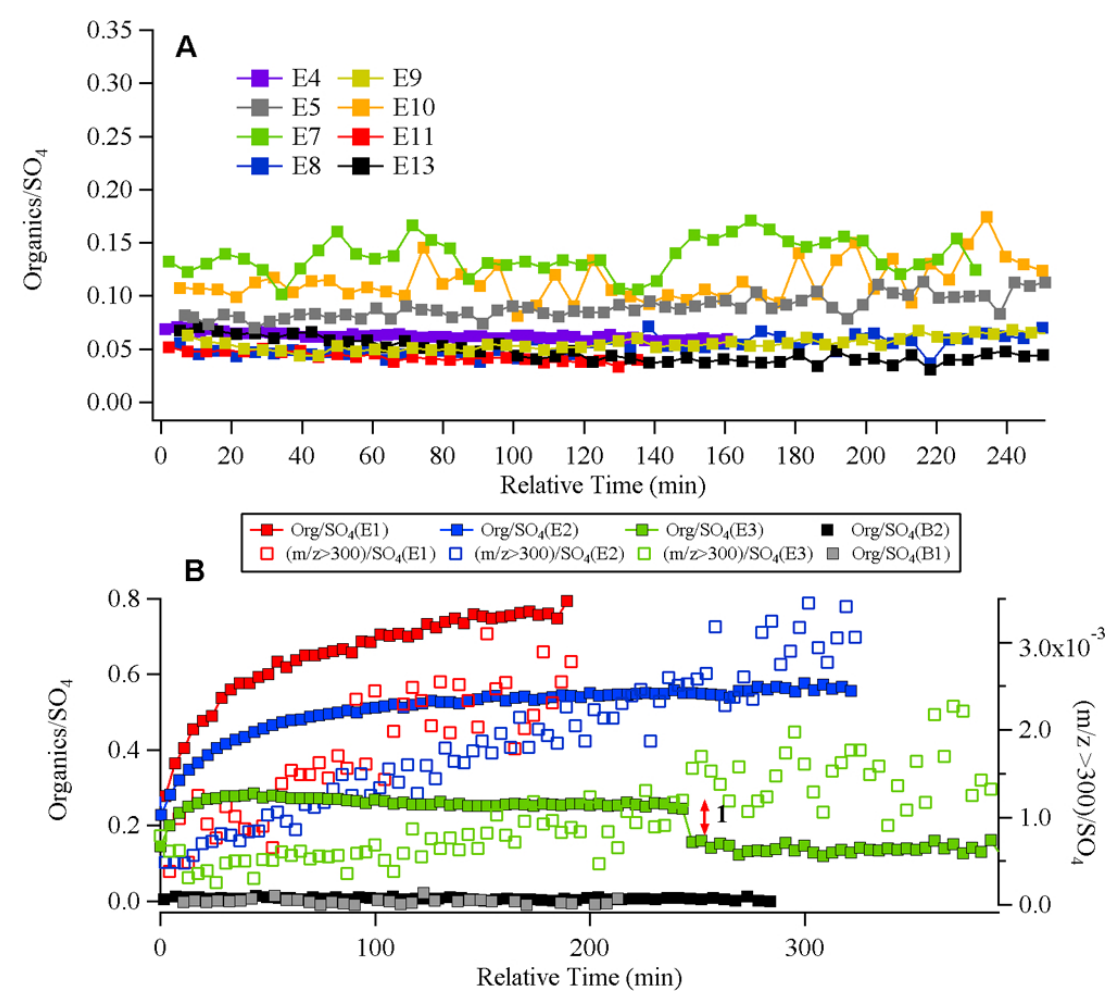

Fig. 1. (A) Organic/sulfate for selected neutral and slightly acidic experiments as a function of time relative to particle $\mathrm{SO}_{4}$ addition. $\mathrm{SO}_{4}$ normalization removes particle wall loss effects. (B) Organic/sulfate and $(\mathrm{m} / z>300) / \mathrm{SO}_{4}$ for highly acidic seed experiments as a function of time relative to particle $\mathrm{SO}_{4}$ addition. Red arrow represents an additional $\mathrm{NH}_{3}$ pulse.

consistent with moderately fresh vehicle emissions, as compared to the values reported for fresh urban plumes $(\sim 3.7$ to 5.2), and in contrast to that of photo-chemically aged air masses (< 1) (De Gouw et al., 2005; Cubison, et al., 2006; Warneke et al., 2007; Vlasenko et al., 2009). Given the multitude of gas phase organic species present in the ambient air, including those of biogenic origin (Table 1), it is possible that other species may partly contribute to organic uptake here (Liggio and Li, 2008) thus explaining some of the small differences in the spectra (This study vs. S.-M. Li et al., 2011). The gas-phase HR-ToF-PTR-MS spectra obtained during experiments with the most acidic seed aerosols (and thus highest added organic mass) are also consistent with an exhaust source rich in unsaturated hydrocarbons as demonstrated previously (Liggio et al., 2011). However, a VOC decrease from the gas-phase for neutral aerosol experiments could not be observed due to the inherently less organic mass taken up during neutral or slightly acidic experiments and thus precision limitations of the HR-ToF-PTR-MS.

\subsubsection{Potential uncertainties}

Given the volatility of ambient OA, the possibility of organic aerosol evaporation during the filtration process followed by re-partitioning to seed aerosol (as a source of additional organic mass) was investigated by comparing the amount and spectra of the organics added to seed aerosol, with the ambient measured OA mass and spectra 10-60 min prior to the addition of seed. The amount of organic mass taken up during neutral aerosol experiments was of similar magnitude to the ambient organic mass concentration prior to seed aerosol exposure (Table 2). Assuming that this ambient organic mass was approximately constant over the $2-3 \mathrm{~h}$ of chamber filling, then upwards of $100 \%$ of the ambient organic aerosol would be required to evaporate to account for the observed uptake to seed aerosol. Additionally, ambient organic aerosol spectra during the time of these experiments were significantly different than that of the added organics to seed aerosol (Fig. 4). The ambient organic aerosol ranged from moderately aged (E10-13; Fig. 4) to highly oxidized (E1; Fig. 4). These observations indicate that repartitioning of organics which may have evaporated from the ambient aerosols during the filtering process is highly unlikely to account for the observed uptake.

As will be demonstrated below, organic mass uptake is enhanced under acidic conditions by aerosol-phase reactions. Given that aerosols in all experiments were initially acidic (due to the aerosol generation method), it is possible that a small fraction of the initial organic mass for neutral aerosol experiments is due to this reactive uptake, which may have occurred for a short time before particles had been fully 

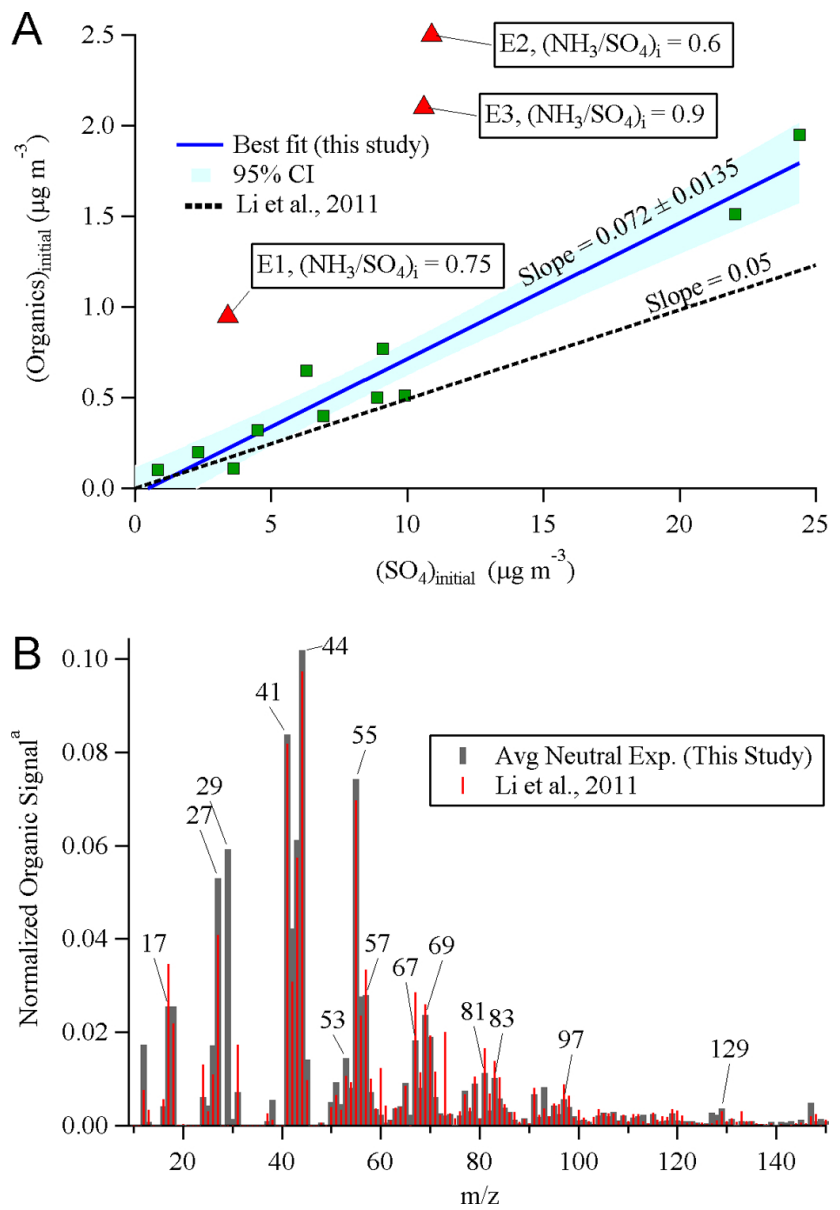

Fig. 2. (A) Initial organics as a function of initial $\mathrm{SO}_{4}$ seed mass $(t \sim 2 \mathrm{~min}$ ) for this study and that of S.-M. Li et al. (2011). Triangles represent highly acidic experiments (E1-E3). Best fit line through green points only. (B) Average organic mass spectra for neutral particle experiments and that of S.-M. Li et al. (2011). ${ }^{a}$ Normalized to the total organic signal.

neutralized. Based upon the rapid aerosol neutralization, the similarity of organic aerosol spectra to that of S.-M. Li et al. (2011) (on neutral aerosol), and the dissimilarity between acidic and neutral aerosol spectra of the current study, it is expected that the reactive uptake organic fraction on finally neutral aerosol is of a minor importance.

The method of seed aerosol addition into the chamber during these experiments contributes further uncertainty to the mechanism of simple condensational uptake of organics. Given that seed aerosol is formed via the formation of $\mathrm{H}_{2} \mathrm{SO}_{4}$ $\left(\mathrm{SO}_{3}+\mathrm{H}_{2} \mathrm{O}\right)$ and subsequent nucleation, the incorporation of organics during the nucleation process cannot be entirely discounted. However, several facts point to the unlikelihood of this event. Firstly, although the role of organics in the nucleation processes has been demonstrated previously, it is usually limited to small dicarboxylic acids and amines (Xu and Zhang, 2012; Yu et al., 2012). No amines were observed in the gas-phase as measured by the PTR-ToF-MS and high $\mathrm{O}: \mathrm{C}$ indicative of small di-acids was not observed in the initial aerosol. Secondly, the large final sulphate mass (5$22 \mu \mathrm{g} \mathrm{m}^{-3} \mathrm{SO}_{4}^{2-}$ ) implies that $\mathrm{H}_{2} \mathrm{SO}_{4}$ vapour concentrations were sufficiently high that molecular collisions with organics were less likely than those of $\mathrm{H}_{2} \mathrm{SO}_{4}$ and $\mathrm{H}_{2} \mathrm{O}$. The high degree of correlation between organic aerosol spectra of this study and that of S.-M. Li et al. (2011) (Fig. 2b), despite the use of atomization as a seed aerosol source (ie: without nucleation) also suggests a minor role for organics in the nucleation process. Finally, organic incorporation during nucleation implies that the initial organic aerosol spectra should be similar for all experiments, as the seed aerosols are generated identically in all cases. However, acidic aerosol experiments have initial spectra that are significantly dissimilar to others (Fig. 5).

\subsubsection{Organic aerosol $\mathrm{O}$ : $\mathrm{C}$ on neutral seed}

The condensation of gasoline exhaust vapours to a polar inorganic seed aerosol suggests that the condensing organics were likely oxygenated to some degree. The $\mathrm{O}: \mathrm{C}$ ratios for ambient aerosols at the time of experiments and those of the added organics (on the seed aerosols) are given in Table 2. The $\mathrm{O}: \mathrm{C}$ ratios in the ambient aerosols ranged from 0.35 0.55 (Mean $=0.42)$, similar to that of a semi-volatile oxygenated secondary organic aerosol (SV-OOA, $\sim 0.35 ; \mathrm{Ng}$ et al., 2010). Conversely, the $\mathrm{O}: \mathrm{C}$ ratios for the organics taken up onto the seed aerosols were substantially lower $(0.21$ 0.32 ; Mean $=0.29$ ), in agreement with that of S.-M. Li et al. (2011), but much higher than that reported for gasoline derived POA ( 0.04) (Mohr et al., 2009), hydrocarbon-like organic aerosols (HOA $\sim 0.05-0.1$ ); a factor thought to represent ambient POA (Ng et al., 2011b), and much lower than that of more aged SOA (less volatile; LV-OOA, $\sim 0.7$ ) (Ng et al., 2010). These observations together point to a mechanism for forming oxygenated OA which is neither as oxygenated as reported surrogates of SOA (OOA; Ng et al., 2011b) nor as hydrocarbon-like as reported primary sources (Mohr et al., 2009; $\mathrm{Ng}$ et al., 2011b) despite a predominantly gasoline exhaust source.

Several factors suggest that the mechanism of organic uptake under these neutral (and near neutral) conditions is likely the dissolution of primary polar gases to a partially aqueous aerosol. Firstly, as was demonstrated in S.-M. Li et al. (2011) a relationship between seed particle volume (as opposed to surface area) and organic mass uptake for aqueous particles implied a solubility mechanism. Similar organic aerosol spectra and seed particle volume dependence in the current study compared to that of S.-M. Li et al. (2011) suggests a similar mechanism. This is also consistent with the fact that the neutral particles in this study began as liquid droplets, and likely contained significant water after neutralization since the chamber RH (40-50\%) was significantly above the efflorescence RH of ammonium sulfate (30-35\%; Smith et al., 

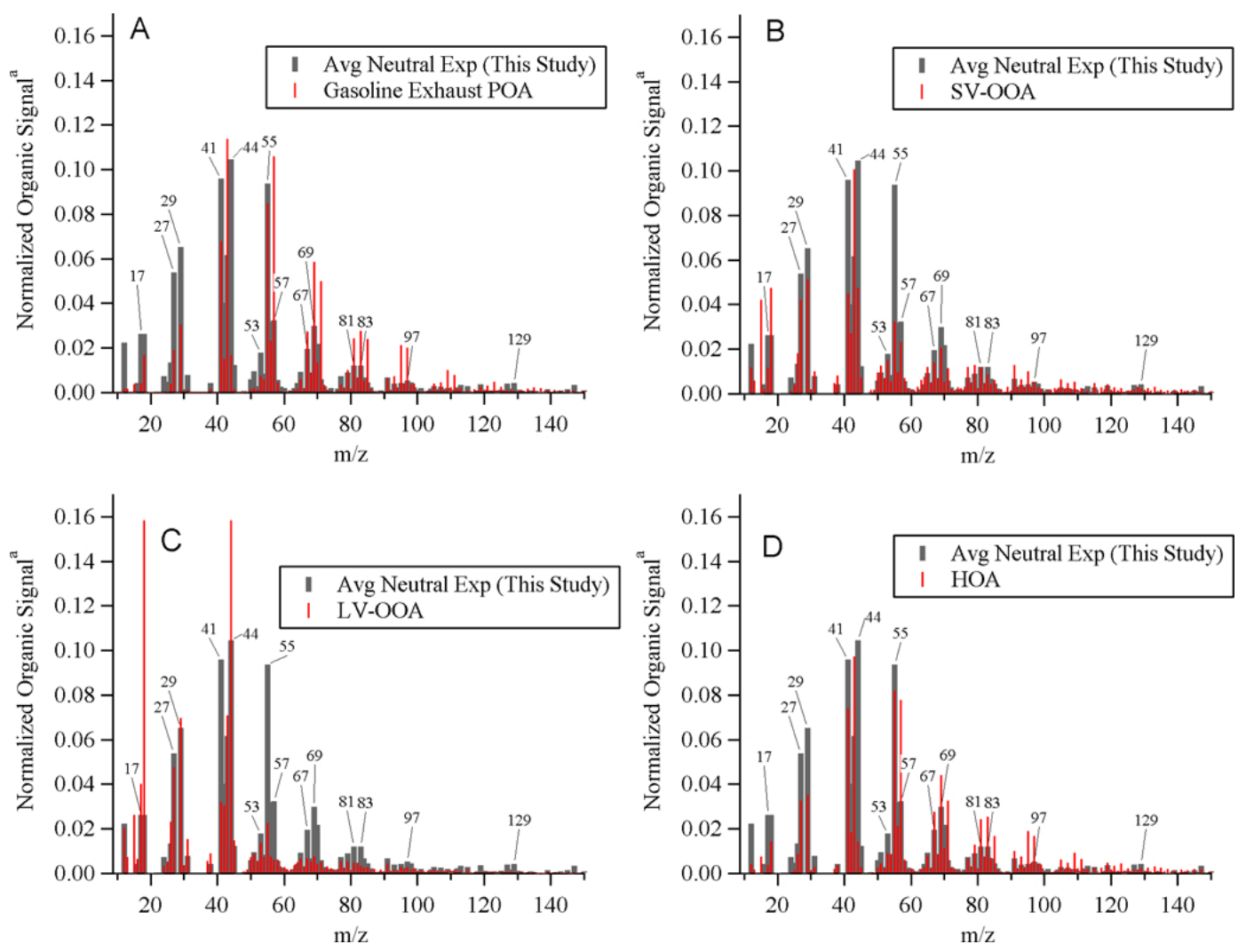

Fig. 3. Comparison of average organic aerosol mass spectrum from initial uptake to $\mathrm{SO}_{4}$ (this study) with those reported for (A) gasoline exhaust POA (Mohr et al., 2009); and various average PMF derived spectra from worldwide datasets (Ng et al., 2011b) including (B). SV-OOA = Semi-volatile oxygenated organic aerosol. (C) LV-OOA = Less-volatile oxygenated organic aerosol. $($ D) HOA = Hydrocarbonlike organic aerosol (surrogate for POA). Reference spectra obtained via AMS Spectral Database; http://cires.colorado.edu/jimenez-group/

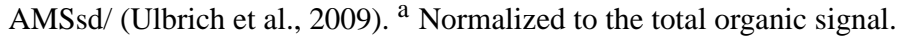

2012). Finally, the equilibrium timescale for organic uptake under these conditions was less than approximately $2 \mathrm{~min}$ (Fig. 1a). This rapid equilibrium is consistent with Henry law solubility, where gas-particle diffusion or gas-interface transport is the rate limiting step. As demonstrated by Shi and Seinfeld (1991) and summarized in Seinfeld and Pandis (1998) the characteristic time for such processes results in an equilibrium achieved on the order of milliseconds to seconds in a closed system. Conversely, equilibrium in a reactive system may take significantly longer (i.e. Fig. 1b) potentially due to slow liquid phase chemistry, or mass transfer limitations caused by the increased organic mass added in acidic experiments resulting in changes in the organic aerosol viscosity (Vaden et al., 2011; Perraud et al., 2012).

In light of the above points, dissolution of primary oxygenated exhaust gases to the seed aerosols, as also shown in S.-M. Li et al. (2011), is likely responsible for much of the oxygen content in the aerosols of this study under neutral (and near neutral) conditions. This is in agreement with recent studies which have demonstrated that carbonyls may account for up to $37 \%$ of the total primary organic mass ( $>80 \%$ in the gas-phase) emitted from light duty gasoline vehicles compared to less than $4 \%$ for diesel (Jakober et al., 2008). Given that reactive organic mass uptake enhanced by acidity is of minor importance for neutral experiments (noted above), it is unlikely that any aerosol reactions such as olefin hydration (Liggio and Li, 2008; Liu et al., 2010) would explain the added oxygen within the neutral and near neutral seed aerosols.

\subsection{Reactive organic uptake on acidic seed}

Experiments with insufficient $\mathrm{NH}_{3}$ for full neutralization of seed aerosols (i.e. acidic, E1-E3) show that acquired organic masses on the seed aerosols are notably above the best fit line of Fig. 2a. This suggests heterogeneous and/or aerosol phase chemistry is occurring, increasing the organic mass by a factor of three above the best fit line, and above that which would immediately partition from the gas-phase to a nonacidic seed aerosol. The existence of aerosol-phase chemistry resulting in oligomers is further demonstrated by the slow increases in organic mass on the aerosols over time during the acidic experiments (Fig. 1b) compared to neutral aerosols which reach a steady state immediately (Fig. 1a). 


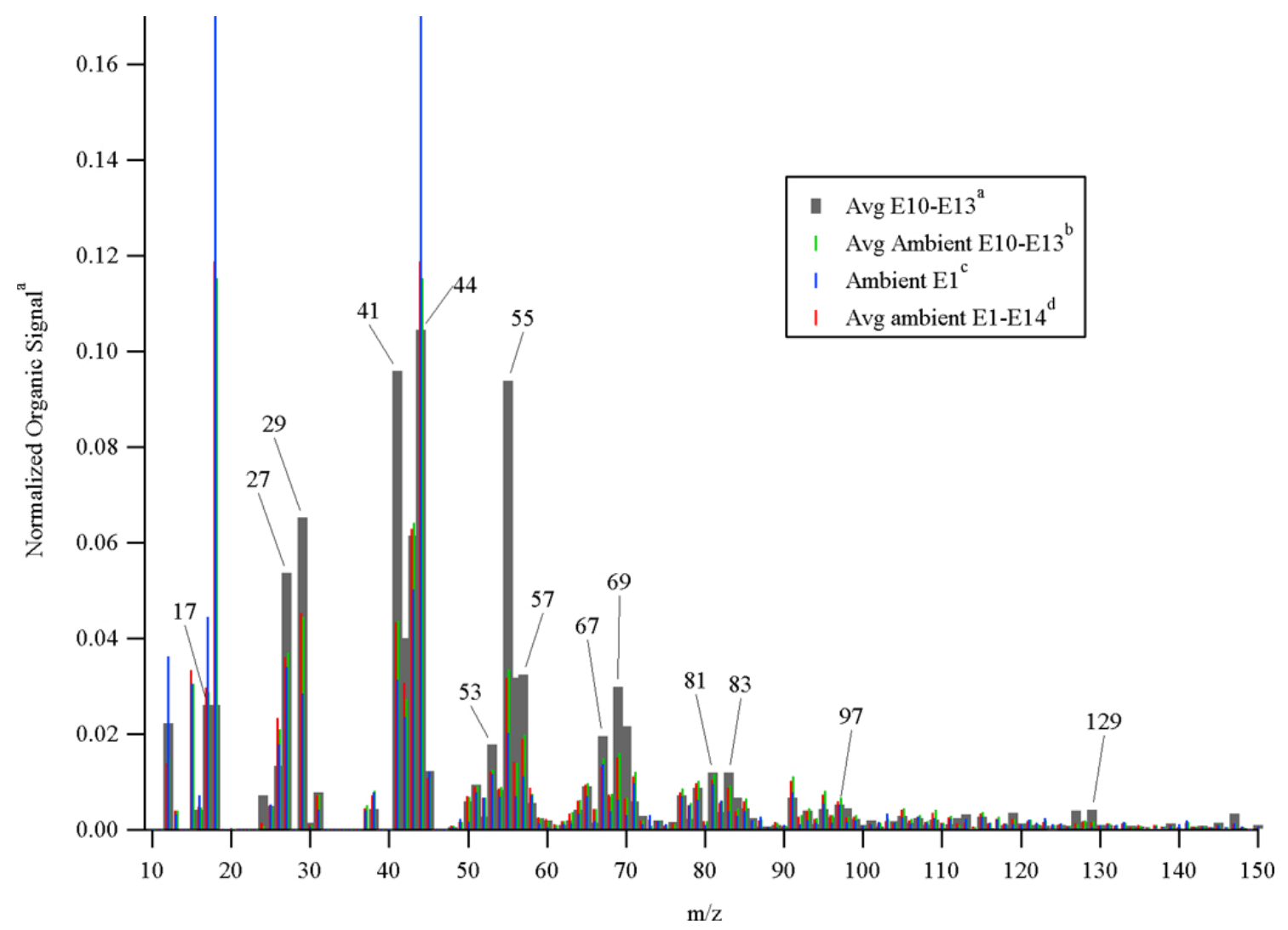

Fig. 4. Comparison of average organic aerosol mass spectrum (non-acidic; this study) with various ambient spectra 10 min prior to exposure in these experiments. ${ }^{a}$ Average (E10-E13) 3 min after uptake. ${ }^{b}$ Average ambient spectra (E10-E13) 10 min prior to exposure. ${ }^{\mathrm{c}}$ Ambient spectra for E1 10 min prior to exposure. ${ }^{\mathrm{d}}$ Average ambient spectra for all experiments 10 min prior to exposure.

Concurrent with aerosol reactive uptake is the formation of high mass fragments in the organic mass spectra of the aerosols (Fig. 5a) which extend beyond 450 amu. Given the large ionization energies utilized in the HR-ToF-AMS $(\sim 70 \mathrm{eV})$, these higher $\mathrm{m} / \mathrm{z}$ fragments are likely to arise from even larger parent compounds in the aerosol, which are highly unlikely to arise from the gas-phase. A shift to larger $m / z$ over time (i.e. chemical reaction) in this closed system is demonstrated in Fig. 5a which shows that the relative importance of fragments greater than $\sim 150 \mathrm{amu}$ increases over several hours $(2 \mathrm{~min}-5 \mathrm{~h})$. Figure $5 \mathrm{~b}$ compares the background raw signal in the absence of particles during this experiment with the spectra at $106 \mathrm{~min}$, which clearly illustrates that fragments as large as $\sim 600 \mathrm{amu}$ are approximately an order of magnitude above the noise level (note Log scale). Conversely, significant high MW fragments were not observed for the fully neutral particle experiments. Although high mass fragments are clearly linked to high MW species, the destructive nature of the AMS ionization precludes the use of these fragments as a quantitative measure of the oligomer fraction. However, a qualitative measure of the oligomers was obtained as the sum of all AMS fragments greater than $300 \mathrm{amu}$. The sum of $\mathrm{m} / z>300$ (normalized by $\mathrm{SO}_{4}$ ) is shown in Fig. $1 \mathrm{~b}$ and demonstrates that there is an obvious difference between the time evolution of high mass fragments and the total organic aerosol mass, with the $m / z>300 / \mathrm{SO}_{4}$ increase being slower without ever reaching a steady state. Also, the rate of increase of $(m / z>300) / \mathrm{SO}_{4}$ is correlated with the final aerosol acidity as determined by the $\mathrm{NH}_{4} / \mathrm{SO}_{4}$ ratio of Table $2(\mathrm{E} 1<\mathrm{E} 2<\mathrm{E} 3)$. Taken together, these observations are consistent with an acidcatalyzed oligomerization mechanism.

\subsubsection{Organic uptake reversibility}

The organic uptake reversibility on acidic aerosol with respect to $\mathrm{NH}_{3}$ exposure, and effect on oligomer formation and aerosol $\mathrm{O}: \mathrm{C}$ ratios was studied by introducing a subsequent pulse of excess $\mathrm{NH}_{3}$ (Fig. 1b, Table 1) after significant organic uptake had occurred which drives the aerosols to neutrality instantly. This results in a corresponding decrease (20-40\%) in the organic mass (Fig. 1b; red arrow), demonstrating a degree of reversibility. In neutralizing the aerosol with $\mathrm{NH}_{3}$, a new gas-particle equilibrium with water vapour must be established; in this case resulting in a decrease in the aerosol water content. A loss of aerosol water and corresponding decrease in organic mass is consistent with the 

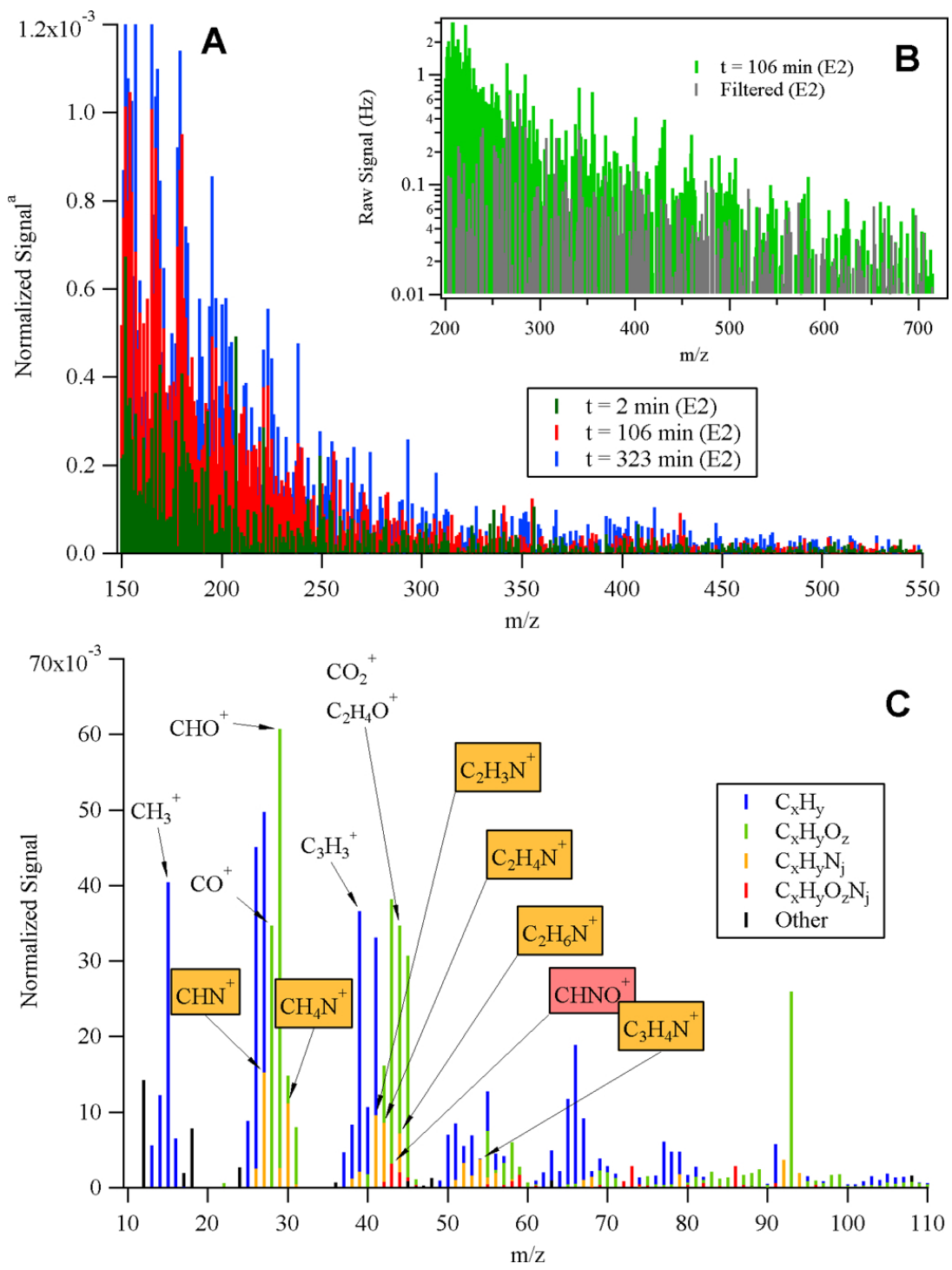

Fig. 5. (A) Organic spectrum (>150 amu) as a function of relative time for E2. ${ }^{\text {a }}$ Normalized to total organic signal. (B) Raw signal $(\mathrm{m} / z>150 \mathrm{amu})$ in the absence of particles (i.e. noise level) during E2 compared to the spectra at 106 min. (C) High resolution Organic aerosol spectrum at the end of a highly acidic experiment (E1). The significant number of $\mathrm{N}$-containing fragments is indicative of imine formation.

known overall reversibility of alkene and carbonyl hydration reactions (Liggio and Li, 2008; Liu et al., 2010; Wade, 2003) as depicted generally in Eqs. (1) and (2).

$\mathrm{R}-\mathrm{CH}=\mathrm{CH}-\mathrm{R}+\mathrm{H}_{2} \mathrm{O} \stackrel{\mathrm{H}^{+}}{\longleftrightarrow} \mathrm{R}-\mathrm{CH}_{2}-\mathrm{CH}(\mathrm{OH})-\mathrm{R}$

$\mathrm{R}-\mathrm{C}(\mathrm{O})-\mathrm{R}+\mathrm{H}_{2} \mathrm{O} \stackrel{\mathrm{H}^{+}}{\longleftrightarrow} \mathrm{R}-\mathrm{C}(\mathrm{OH})_{2}-\mathrm{R}$

It may also be possible that the neutralization of the aerosol results in OA evaporation which accompanies the loss of sulphuric acid/water liquid phase that the OA was dissolved in. Given the evidence for reactive uptake in acidic particles forming large MW species, simple OA evaporation is less likely. Equations (1) and (2) are also the first steps to other reactions leading to oligomeric compounds such aldol, acetal, imine and cationic polymerization products (Noziere and Riemer, 2003; Liggio et al., 2007; Wang et al., 2010) some of which are not formed through reversible reactions or require an acid catalyst in the forward and reverse directions. The formation of products from irreversible reactions would also slow the eventual shift in equilibrium back to the starting olefin (Eq. 1) via ambient ozonolysis reaction (e.g. Morris et al., 2002). Indeed, under acidic conditions a number of nitrogen containing fragments were observed in the organic aerosol spectra, as depicted in Fig. 5c, possibly as a result of acid catalyzed irreversible imine formation reactions (Wang et al., 2010). The irreversible formation of these and other 

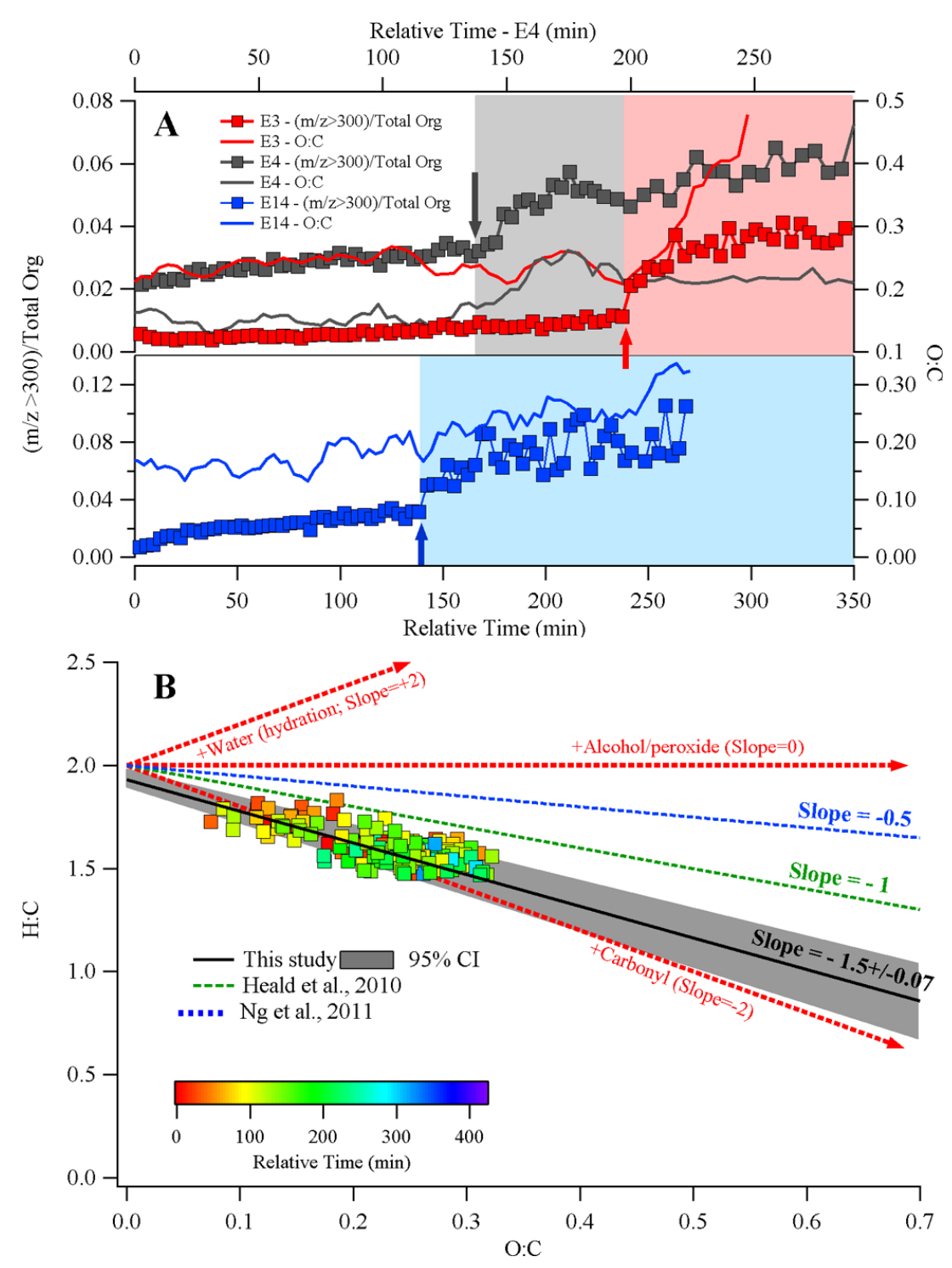

Fig. 6. (A) Relative importance of $>300$ amu fragments to the total organics and associated organic $\mathrm{O}$ : $\mathrm{C}$ before and after the addition of an $\mathrm{NH}_{3}$ pulse (shaded areas). Coloured arrows depict the point of $\mathrm{NH}_{3}$ addition. (B) VanKrevelen diagram for experiments which remain acidic (E1-E4, E14), with the slopes from previous ambient studies.

products may explain why the oligomerization products, as represented by $(m / z>300) / \mathrm{SO}_{4}$ in Fig. $1 \mathrm{~b}$ do not decrease upon addition of $\mathrm{NH}_{3}$ and subsequent aerosol neutralization. However, even reversibly formed oligomers are likely stable in the absence of an acid catalyst. This behaviour was only observed in experiments with the highest acidity, while addition of excess ammonia during a neutral aerosol experiment (E5) did not result in any significant loss of organics.

\subsubsection{Organic aerosol $\mathrm{O}: \mathrm{C}$ on acidic seed}

The addition of $\mathrm{NH}_{3}$ resulting in the partial reversibility of organic uptake can also give an indication of the degree of oxygenation of the high MW products and their starting ma- terials. The fraction of the total organic fragments attributed to high MW fragments (using $(m / z>300) / T o t a l$ Org as a surrogate) and the organic $\mathrm{O}: \mathrm{C}$ ratios for three experiments with an additional $\mathrm{NH}_{3}$ pulse is given in Fig. 6 a. The $\mathrm{O}: \mathrm{C}$ ratio is determined for fragments up to $150 \mathrm{amu}$, which encompasses $>95 \%$ of the total organic mass. Figure 6a demonstrates that the relative importance of high MW products increases as a result of aerosol neutralization (shaded regions) at the expense of reversibly formed products, and that this effect is more prominent for the most highly acidic experiments. This is consistent with the $(m / z>300) / \mathrm{SO}_{4}$ of Fig. 1b, where high MW products are formed through effectively irreversible reactions, thus accounting for a greater fraction of the organic aerosol after the loss of products 
via reversible reactions. More importantly, the corresponding $\mathrm{O}: \mathrm{C}$ ratios increased after the $\mathrm{NH}_{3}$ addition (Fig. 6a), and most notably for the more acidic experiments. This implies that the irreversibly formed oligomers were more oxygenated than the reversibly formed uptake species, and that the oligomers arose from more oxygenated building blocks, facilitated by the increased aerosol acidity. If it is assumed that what remains after neutralization is primarily high $\mathrm{MW}$ products, then they likely will possess an $\mathrm{O}: \mathrm{C}$ ratio greater than $\sim 0.3$. Changes in the $\mathrm{O}: \mathrm{C}$ ratios over time were not observed for experiments with completely neutral aerosols (E5E7; E9-E13), suggesting that acidity played a key role in the evolution of the $\mathrm{O}: \mathrm{C}$ ratios observed in the acidic aerosol experiments.

The evolution of the organic $\mathrm{O}: \mathrm{C}$ ratios during these experiments can also be represented in a Van Krevelen diagram (Fig. 6b), as has been shown for ambient and laboratory SOA datasets (Tkacik et al., 2012; Lambe et al., 2012; Heald et al., 2010; Ng et al., 2011a). The slope of the lines in Fig. 6b represent the net functional group changes in the idealized case (red dashed lines), ambient observations (blue and green), and the current study (black). For the most highly acidic cases, where sufficient organic mass was taken up on the seed aerosols to allow for a reliable elemental composition determination (E1-E4; E14), the data fall along a slope of approximately -1.5 . This is significantly less than has been observed for ambient or laboratory SOA $(-0.5$ to -1$)$, where gas-phase/heterogeneous oxidation, multiple source inputs and/or dilution determine the slope. In the present study, the combination of primary oxygenated and hydrocarbon condensation (i.e. S.-M. Li et al., 2011) and oligomer formation results in a net conversion from hydrocarbon-like to approaching carbonyl functionality (slope $=-2$ ). A steep slope indicative of carbonyl addition has been observed previously in oxidative systems ( $\mathrm{Ng}$ et al., 2011a). In contrast, the slope in this study is facilitated by the aerosol-phase chemistry, enhanced by particle acidity. As noted above, such an evolution in elemental composition is only observed for the most acidic experiments, highlighting the importance of acidity in the reactive uptake and hence evolution of organic aerosol $\mathrm{O}: \mathrm{C}$. These results further imply that hydration reactions while possibly important in the first few minutes, are not responsible for the changes in the $\mathrm{O}: \mathrm{C}$ ratios or the majority of the organic mass. Hydration reactions should result in a positive (i.e. upwards; +2) slope (Fig. 6b), however there was insufficient time resolution in these measurements to observe this behaviour. A trajectory in the Van Krevelen space towards higher $\mathrm{O}: \mathrm{C}$ ratios is in agreement with the increased relative importance of high MW species (which have a higher $\mathrm{O}: \mathrm{C}$ ratio) over time as demonstrated in Fig. 6a. These are formed on a slower time scale than the condensation of primary gases and/or fast hydration reactions. The slope is consistent with hemi-acetal and/or aldol reaction mechanisms, forming oligomeric species containing carbonyl functional groups (Nguyen et al., 2010; Z. Li et al., 2011). Increases in $\mathrm{O}: \mathrm{C}$ over time, possibly due to oxidative chemistry in the dark (i.e. $\mathrm{O}_{3}$ and $\mathrm{NO}_{3}$ ) are not likely, since a large and evolving organic mass and $\mathrm{O}: \mathrm{C}$ was only observed for acidic aerosol experiments, while ozone was likely present in small amounts during all experiments. Regardless, ozone chemistry forming SOA is likely too slow to form the large amount of organic mass observed here on such a short time scale (both in acidic and neutral experiments).

\section{Implications and conclusions}

The present results have several different implications for ambient organic OA mass and composition in the presence of either neutral or acidic aerosol. Foremost, they imply that the dissolution of gasoline exhaust vapours onto pre-existing neutral seed mass as demonstrated previously (S.-M. Li et al., 2011), will occur under ambient conditions (with fully diluted exhaust). Extrapolating the relationship in Fig. 2a (Organic: $\mathrm{SO}_{4} \sim 7 \%$ ) to a regional scale, downwind of urban sources $\left(\sim 2 \mu \mathrm{g} \mathrm{m}^{-3}\right.$ neutral $\mathrm{SO}_{4}$; Zhang et al., 2007$)$ suggests that $\sim 0.14 \mu \mathrm{g} \mathrm{m}^{-3}$ of organics can be added to the OA burden via this mechanism. This amount of organic mass is small with respect to typical SOA levels in these regions; $\sim 1.5-5.4 \mu \mathrm{g} \mathrm{m}^{-3}$ OOA (Zhang et al., 2007). However, under neutral conditions assuming a simple solubility mechanism for primary gases, this uptake should be considered to be primary. Thus this dissolution of primary polar organics represents a significant amount of POA compared to the average POA (represented by HOA) measured in these areas ( $\sim 0.6 \mu \mathrm{g} \mathrm{m}^{-3}$; Zhang et al., 2007). Furthermore, this process represents a source of oxygenated OA that can be categorized as POA (i.e. dissolution of primary gases). In principle, the dissolution of secondary oxygenated VOCs into an aqueous sulphate aerosol is also possible, and perhaps more important given their tendency to be more highly oxygenated.

Typically, OA and/or oxygenated PMF factors (i.e. LV, SVOOA) correlate well with secondary sulphate (Huang et al., 2011; Hersey et al., 2011), from which a secondary source is inferred. However in this study the organic uptake is demonstrated to be both proportional to the $\mathrm{SO}_{4}$ mass and with relatively high $\mathrm{O}: \mathrm{C}$ ratios, which implies that a fraction of the measured oxygenated OA, which correlates with secondary sulphate and assigned as SOA, may in fact be primary in nature. Indeed, in using the PMF technique to determine contributing factors to a dataset collected in mid continental North American regional ambient air, Slowik et al. (2011) derived an AMS PMF factor which correlated with $\mathrm{SO}_{4}$ but which they could not attribute to specific processes. This unknown factor does have a spectrum with some qualitatively similar major fragments to those presented here. However, the current finding suggests that, due to the correlation with sulphate, it is unlikely that spectra from this process can be resolved from SOA factors derived from PMF analysis of aerosol mass spectral data. 
Conversely, organic mass uptake in the present study, utilizing the ambient mixture and concentration of gases is greatly enhanced under acidic conditions, due to aerosolphase reactions forming products which are more oxygenated than dissolved species on neutral aerosols. In this case, the reactive uptake facilitated by acidity should be considered an additional source of SOA, since both primary and secondary gases are transformed to other products within the aerosol. Consequently, ambient aerosols which are initially acidic, can add significant amounts of organic mass, and with a high degree of oxygenation via reactive uptake in a very short time, despite being neutralized shortly thereafter (i.e. effectively irreversible). Since significant mass is taken up in less than 2 min under these acidic conditions, this process is highly relevant for freshly nucleated aerosols, during cloud processing of sulphate, or anywhere that acidic sulphate or other acidic substances are available for even a short time. These results strongly suggest that similar oxygenated organic mass and high molecular weight products formed in this manner are ubiquitous in areas of moderate to high levels of $\mathrm{SO}_{2}$ and/or other acid-forming precursors and enhanced further at low $\mathrm{NH}_{3}$. The results also imply that on-going aerosol chemistry facilitated by acidity can affect to the $\mathrm{O}: \mathrm{C}$ ratio evolution in ambient $\mathrm{OA}$ as depicted in Van Krevelen diagrams, without the need for oxidation to occur. These two processes under neutral and acidic conditions, and their effect on ambient $\mathrm{O}: \mathrm{C}$ ratios, have not been previously considered, but will be important in properly representing organic aerosol $\mathrm{O}: \mathrm{C}$ ratios in air quality and climate models.

Acknowledgements. The authors would like to thank Alexander Vlasenko for his PTR-ToF-MS measurements, the National Agricultural Emissions Standards Initiative (NAESI) and the Clean Air Regulatory Agenda (CARA) for funding.

Edited by: V. F. McNeill

\section{References}

Aiken, A. C., DeCarlo, P. F., and Jimenez, J. L.: Elemental Analysis of Organic Species with Electron Ionization High-Resolution Mass Spectrometry, Anal. Chem., 79, 8350-8358, 2007.

Aiken, A. C., Decarlo, P. F., Kroll, J. H., Worsnop, D. R., Huffman, J. A., Docherty, K. S., Ulbrich, I. M., Mohr, C., Kimmel, J. R., Sueper, D., Sun, Y., Zhang, Q., Trimborn, A., Northway, M., Ziemann, P. J., Canagaratna, M. R., Onasch, T. B., Alfarra, M. R., Prevot, A. S. H., Dommen, J., Duplissy, J., Metzger, A., Baltensperger, U., and Jimenez, J. L.: O/C and OM/OC ratios of primary, secondary, and ambient organic aerosols with high-resolution time-of-flight aerosol mass spectrometry, Environ. Sci. Technol., 42, 4478-4485, 2008.

Baker, J., Ashbourn, S. F. M., and Cox, R. A.: Heterogeneous reactivity of nitrous acid on submicron sulfuric acid aerosol, Phys. Chem. Chem. Phys., 1, 683-690, 1999.

Chan, T. W. and Mozurkewich, M.: Measurement of the coagulation rate constant for sulfuric acid particles as a function of particle size using tandem differential mobility analysis, Atmos. Environ., 32, 321-329, 2001.

Chirico, R., DeCarlo, P. F., Heringa, M. F., Tritscher, T., Richter, R., Prévôt, A. S. H., Dommen, J., Weingartner, E., Wehrle, G., Gysel, M., Laborde, M., and Baltensperger, U.: Impact of aftertreatment devices on primary emissions and secondary organic aerosol formation potential from in-use diesel vehicles: results from smog chamber experiments, Atmos. Chem. Phys., 10, 11545-11563, doi:10.5194/acp-10-11545-2010, 2010.

Cubison, M. J., Alfarra, M. R., Allan, J., Bower, K. N., Coe, H., McFiggans, G. B., Whitehead, J. D., Williams, P. I., Zhang, Q., Jimenez, J. L., Hopkins, J., and Lee, J.: The characterisation of pollution aerosol in a changing photochemical environment, Atmos. Chem. Phys., 6, 5573-5588, doi:10.5194/acp-6-5573-2006, 2006.

Denkenberger, K., Moffet, R., Holecek, J., Rebotier, T., and Prather, K.: Real-Time, Single-Particle Measurements of Oligomers in Aged Ambient Aerosol Particles, Environ. Sci. Technol., 41, 5439-5446, 2007.

DeCarlo, P. F., Kimmel, J. R., Trimborn, A., Northway, M. J., Jayne, J. T., Aiken, A. C., Gonin, M., Fuhrer, K., Horvath, T., Docherty, K. S., Worsnop, D. R., and Jimenez, J. L.: Field-deployable, high-resolution, time-of-flight aerosol mass spectrometer, Anal. Chem., 78, 8281-8289, doi:10.1021/ac061249n, 2006.

De Gouw, J. A., Middlebrook, A. M., Warneke, C., Goldan, P. D., Kuster, W. C., Roberts, J. M., Fehsenfeld, F. C., Worsnop, D. R., Canagaratna, M. R., Pszenny, A. A. P., Keene, W. C., Marchewka, M., Bertman, S. B., and Bates, T. S.: Budget of organic carbon in a polluted atmosphere: Results from the New England Air Quality Study in 2002, J. Geophys. Res., 110, 1-22, 2005.

Gao, S., Ng, N., Keywood, M., Varutbangkul, V., Bahreini, R., Nenes, A., He, J., Yoo, K., Beauchamp, J., Hodyss, R., Flagan, R., and Seinfeld, J.: Particle Phase Acidity and Oligomer Formation in Secondary Organic Aerosol, Environ. Sci. Technol., 38, 6582-6589, 2004.

Hall IV, W. A. and Johnston, M. V.: Oligomer content of $\alpha$-pinene secondary organic aerosol, Aerosol Sci. Technol., 45, 37-45, 2011.

Heald, C., Kroll, J., Jimenez, J., Docherty, K., DeCarlo, P. F., Aiken, A., Chen, Q., Martin, S., Farmer, D., and Artaxo, P.: A simplified description of the evolution of organic aerosol in the atmosphere, Geophys. Res. Lett., 37, L08803, doi:10.1029/2010GL042737, 2010.

Hersey, S. P., Craven, J. S., Schilling, K. A., Metcalf, A. R., Sorooshian, A., Chan, M. N., Flagan, R. C., and Seinfeld, J. H.: The Pasadena Aerosol Characterization Observatory (PACO): chemical and physical analysis of the Western Los Angeles basin aerosol, Atmos. Chem. Phys., 11, 7417-7443, doi:10.5194/acp11-7417-2011, 2011.

Huang, X.-F., He, L.-Y., Hu, M., Canagaratna, M. R., Kroll, J. H., Ng, N. L., Zhang, Y.-H., Lin, Y., Xue, L., Sun, T.-L., Liu, X.-G., Shao, M., Jayne, J. T., and Worsnop, D. R.: Characterization of submicron aerosols at a rural site in Pearl River Delta of China using an Aerodyne High-Resolution Aerosol Mass Spectrometer, Atmos. Chem. Phys., 11, 1865-1877, doi:10.5194/acp-11-18652011, 2011.

Huffman, J. A., Docherty, K. S., Mohr, C., Cubison, M. J., Ulbrich, I. M., Ziemann, P. J., Onasch, T. B., and Jimenez, J. L.: 
Chemically-resolved volatility measurements of organic aerosol from different sources, Environ. Sci. Technol., 43, 5351-5357, 2009.

Jakober, C. A., Robert, M. A., Riddle, S. G., Destaillats, H., Charles, M. J., Green, P. G., and Kleeman, M. J.: Carbonyl emissions from gasoline and diesel motor vehicles, Environ. Sci. Technol., 42, 4697-4703, 2008.

Jimenez, J. L., Canagaratna, M. R., Donahue, N. M., Prevot, A. S. H., Zhang, Q., Kroll, J. H., DeCarlo, P. F., Allan, J. D., Coe, H., Ng, N. L., Aiken, A. C., Docherty, K. S., Ulbrich, I. M., Grieshop, A. P., Robinson, A. L., Duplissy, J., Smith, J. D., Wilson, K. R., Lanz, V. A., Hueglin, C., Sun, Y. L., Tian, J., Laaksonen, A., Raatikainen, T., Rautiainen, J., Vaattovaara, P., Ehn, M., Kulmala, M., Tomlinson, J. M., Collins, D. R., Cubison, M. J., Dunlea, E. J., Huffman, J. A., Onasch, T. B., Alfarra, M. R., Williams, P. I., Bower, K., Kondo, Y., Schneider, J., Drewnick, F., Borrmann, S., Weimer, S., Demerjian, K., Salcedo, D., Cottrell, L., Griffin, R., Takami, A., Miyoshi, T., Hatakeyama, S., Shimono, A., Sun, J. Y., Zhang, Y. M., Dzepina, K., Kimmel, J. R., Sueper, D., Jayne, J. T., Herndon, S. C., Trimborn, A. M., Williams, L. R., Wood, E. C., Middlebrook, A. M., Kolb, C. E., Baltensperger, U., and Worsnop, D. R.: Evolution of organic aerosols in the atmosphere, Science, 326, 1525-1529, doi:10.1126/science.1180353, 2009.

Jordan, A., Haidachera, S., Hanel, G., Hartungena, E., Märk, L., Seehauser, H., Schottkowsky, R., Sulzer, P., and Märk, T. D.: A high resolution and high sensitivity proton-transfer-reaction time-of-flight mass spectrometer (PTR-TOF-MS), Int. J. Mass Spectrom., 286, 122-128, 2009.

Kroll, J. H., Donahue, N. M., Jimenez, J. L., Kessler, S. H., Canagaratna, M. R., Wilson, K. R., Altieri, K. E., Mazzoleni, L. R., Wozniak, A. S., Bluhm, H., Mysak, E. R., Smith, J. D., Kolb, C. E., and Worsnop, D. R.: Carbon oxidation state as a metric for describing the chemistry of atmospheric organic aerosol, Nat. Chem., 3, 133-139, doi:10.1038/nchem.948, 2011.

Lambe, A., Onasch, T. B., Croasdale, D. R., Wright, J. P., Martin, A. T., Franklin, J. P., Massoli, P., Kroll, J. H., Canagaratna, M. R., Brune, W. H., Worsnop, D. R., and Davidovits, P.: Transitions from Functionalization to Fragmentation Reactions of Laboratory Secondary Organic Aerosol (SOA) Generated from the OH Oxidation of Alkane Precursors, Environ. Sci. Technol., 46, 5430-5437, doi.org/10.1021/es300274t, 2012.

Li, S.-M., Liggio, J., Graham, L., Lu, G., Brook, J., Stroud, C., Zhang, J., Makar, P., and Moran, M. D.: Condensational uptake of semivolatile organic compounds in gasoline engine exhaust onto pre-existing inorganic particles, Atmos. Chem. Phys., 11, 10157-10171, doi:10.5194/acp-11-10157-2011, 2011.

Li, Z., Schwier, A. N., Sareen, N., and McNeill, V. F.: Reactive processing of formaldehyde and acetaldehyde in aqueous aerosol mimics: surface tension depression and secondary organic products, Atmos. Chem. Phys., 11, 11617-11629, doi:10.5194/acp11-11617-2011, 2011.

Liggio, J. and Li, S.-M.: Reversible and irreversible processing of biogenic olefins on acidic aerosols, Atmos. Chem. Phys., 8, 2039-2055, doi:10.5194/acp-8-2039-2008, 2008.

Liggio, J., Li, S.-M., Brook, J. R., and Mihele, C.: Direct Polymerization of Isoprene and $\alpha$-Pinene on Acidic Aerosols, Geophys. Res. Lett., 34, L05814, doi:10.1029/2006GL028468, 2007.
Liggio, J., Li, S.-M., Vlasenko, A., Sjostedt, S., Chang, R., Shantz, N., Abbatt, J., Slowik, J. G., Bottenheim, J. W., Brickell, P. C., Stroud, C., and Leaitch, W. R.: Primary and Secondary Organic Aerosols in Urban Air Masses Intercepted at a Rural Site, J. Geophys. Res., 115, D21305, doi:10.1029/2010JD014426, 2010.

Liggio, J., Li, S., Vlasenko, A., Stroud, C., and Makar, P.: Depression of ammonia uptake to sulfuric acid aerosols by competing uptake of ambient organic gases, Environ. Sci. Technol., 45, 2790-2796, 2011.

Liu, Z., Ge, M., Yin, S., and Wang, W.: Uptake and reaction kinetics of $\alpha$-pinene and $\beta$-pinene with sulfuric acid solutions, Chem. Phys. Lett., 491, 146-150, 2010.

Matthew, B. M., Middlebrook, A. M., and Onasch, T. B.: Collection Efficiencies in an Aerodyne Aerosol Mass Spectrometer as a Function of Particle Phase for Laboratory Generated Aerosols, Aerosol Sci. Technol., 42, 884-898, 2008.

Mohr, C., Huffman, J. A., Cubison, M. J., Aiken, A. C., Docherty, K. S., Kimmel, J. R., Ulbrich, I. M., Hannigan, M., and Jimenez, J. L.: Characterization of primary organic aerosol emissions from meat cooking, trash burning, and motor vehicles with highresolution aerosol mass spectrometry and comparison with ambient and chamber observations, Environ. Sci. Technol., 43, 2443-2449, 2009.

Morris, J. W., Davidovits, P., Jayne, J. T., Jimenez, J. L., Shi, Q., Kolb, C. E., Worsnop, D. R., Barney, W. S., and Cass, G.: Kinetics of submicron oleic acid aerosols with ozone: A novel aerosol mass spectrometric technique, Geophys. Res. Lett., 29, 71-1-714, 2002.

Murphy, B. N., Donahue, N. M., Fountoukis, C., and Pandis, S. N.: Simulating the oxygen content of ambient organic aerosol with the 2D volatility basis set, Atmos. Chem. Phys., 11, 7859-7873, doi:10.5194/acp-11-7859-2011, 2011.

Ng, N. L., Canagaratna, M. R., Zhang, Q., Jimenez, J. L., Tian, J., Ulbrich, I. M., Kroll, J. H., Docherty, K. S., Chhabra, P. S., Bahreini, R., Murphy, S. M., Seinfeld, J. H., Hildebrandt, L., Donahue, N. M., DeCarlo, P. F., Lanz, V. A., Prévôt, A. S. H., Dinar, E., Rudich, Y., and Worsnop, D. R.: Organic aerosol components observed in Northern Hemispheric datasets from Aerosol Mass Spectrometry, Atmos. Chem. Phys., 10, 46254641, doi:10.5194/acp-10-4625-2010, 2010.

Ng, N. L., Canagaratna, M. R., Jimenez, J. L., Chhabra, P. S., Seinfeld, J. H., and Worsnop, D. R.: Changes in organic aerosol composition with aging inferred from aerosol mass spectra, Atmos. Chem. Phys., 11, 6465-6474, doi:10.5194/acp-11-64652011, 2011a.

Ng, N. L., Canagaratna, M. R., Jimenez, J. L., Zhang, Q., Ulbrich, I. M., and Worsnop, D. R.: Real-time methods for estimating organic component mass concentrations from aerosol mass spectrometer data, Environ. Sci. Technol., 45, 910-916, 2011 b.

Nguyen, T. B., Bateman, A. P., Bones, D. L., Nizkorodov, S. A., Laskin, J., and Laskin, A.: High-resolution mass spectrometry analysis of secondary organic aerosol generated by ozonolysis of isoprene, Atmos. Environ., 44, 1032-1042, 2010.

Nguyen, T. B., Laskin, J., Laskin, A., and Nizkorodov, S. A.: Nitrogen-containing organic compounds and oligomers in secondary organic aerosol formed by photooxidation of isoprene, Environ. Sci. Technol., 45, 6908-6918, doi:10.1021/es201611n, 2011. 
Noziere, B. and Riemer, D. D.: The chemical processing of gas-phase carbonyl compounds by sulfuric acid aerosols: 2,4pentanedione, Atmos. Environ., 37, 841-851, 2003.

Perraud, V., Bruns, E. A., Ezell, M. J., Johnson, S. N., Yu, Y., Alexander, M. L., and Finlayson-Pitts, B. J.: Nonequilibrium atmospheric secondary organic aerosol formation and growth, $\mathrm{P}$. Natl. Acad. Sci. USA, 109, 2836-2841, 2012.

Seinfeld, J. and Pandis, S.: Atmospheric Chemistry and Physics From Air Pollution to Climate Change, John Wiley \& Sons Incorporated, New York, 1998.

Shi, B. and Seinfeld, J. H.: On mass transport limitation to the rate of reaction of gases in liquid droplets, Atmos. Environ., 25A, 2371-2383, 1991.

Slowik, J. G., Brook, J., Chang, R. Y.-W., Evans, G. J., Hayden, K., Jeong, C.-H., Li, S.-M., Liggio, J., Liu, P. S. K., McGuire, M., Mihele, C., Sjostedt, S., Vlasenko, A., and Abbatt, J. P. D.: Photochemical processing of organic aerosol at nearby continental sites: contrast between urban plumes and regional aerosol, Atmos. Chem. Phys., 11, 2991-3006, doi:10.5194/acp-11-29912011, 2011.

Smith, M. L., Bertram, A. K., and Martin, S. T.: Deliquescence, efflorescence, and phase miscibility of mixed particles of ammonium sulfate and isoprene-derived secondary organic material, Atmos. Chem. Phys., 12, 9613-9628, doi:10.5194/acp-12-96132012, 2012.

Sun, Y.-L., Zhang, Q., Schwab, J. J., Demerjian, K. L., Chen, W.N., Bae, M.-S., Hung, H.-M., Hogrefe, O., Frank, B., Rattigan, O. V., and Lin, Y.-C.: Characterization of the sources and processes of organic and inorganic aerosols in New York city with a high-resolution time-of-flight aerosol mass apectrometer, Atmos. Chem. Phys., 11, 1581-1602, doi:10.5194/acp-11-15812011, 2011.

Tkacik, D. S., Presto, A. A., Donahue, N. M., and Robinson, A. L.: Secondary Organic Aerosol Formation from Intermediate-Volatility Organic Compounds: Cyclic, Linear, and Branched Alkanes, Environ. Sci. Technol., 46, 8773-8781, doi.org/10.1021/es301112c, 2012.

Ulbrich, I. M., Canagaratna, M. R., Zhang, Q., Worsnop, D. R., and Jimenez, J. L.: Interpretation of organic components from Positive Matrix Factorization of aerosol mass spectrometric data, Atmos. Chem. Phys., 9, 2891-2918, doi:10.5194/acp-9-2891-2009, 2009.

Vaden, T. D., Imre, D., Beránek, J., Shrivastava, M., and Zelenyuk, A.: Evaporation kinetics and phase of laboratory and ambient secondary organic aerosol, P. Natl. Acad. Sci. USA, 108, 21902195, 2011.

Vlasenko, A., Slowik, J. G., Bottenheim, J. W., Brickell, P. C., Chang, R. Y. W., Macdonald, A. M., Shantz, N. C., Sjostedt, S. J., Wiebe, H. A., Leaitch, W. R., and Abbatt, J. P. D.: Measurements of VOCs by proton transfer reaction mass spectrometry at a rural Ontario 10 site: Sources and correlation to aerosol composition, J. Geophys. Res.-Atmos., 114, D21305, doi:10.1029/2009JD012025, 2009.
Volkamer, R., Jimenez, J. L., San Martini, F., Dzepina, K., Zhang, Q., Salcedo, D., Molina, L. T., Worsnop, D. R., and Molina, M. J.: Secondary organic aerosol formation from anthropogenic air pollution: Rapid and higher than expected, Geophys. Res. Lett., 33, L17811, doi:10.1029/2006GL026899, 2006.

Wade, L. G.: Organic chemistry, Prentice Hall, Upper Saddle River, N.J., 2003.

Wang, X., Gao, S., Yang, X., Chen, H., Chen, J., Zhuang, G., Surratt, J. D., Chan, M. N., and Seinfeld, J. H.: Evidence for high molecular weight nitrogen-containing organic salts in urban aerosols, Environ. Sci. Technol., 44, 4441-4446, 2010.

Warneke, C., McKeen, S. A., de Gouw, J. A., Goldan, P. D., Kuster, W. C., Holloway, J. S., Williams, E. J., Lerner, B. M., Parrish, D. D., Trainer, M., Fehsenfeld, F. C., Kato, S., Atlas, E. L., Baker, A., and Blake, D. R.: Determination of urban volatile organic compound emission ratios and comparison with an emissions database, J. Geophys. Res., 112, D10S47, doi:10.1029/2006JD007930, 2007.

$\mathrm{Xu}, \mathrm{W}$. and Zhang, R.: Theoretical Investigation of Interaction of Dicarboxylic Acids with Common Aerosol Nucleation Precursors, J. Phys. Chem. A, 116, 4539-4550, 2012.

Yu, H., McGraw, R., and Lee, S.-H.: Effects of amines on formation of sub-3nm particles and their subsequent growth, Geophys. Res. Lett., 39, L02807, doi:10.1029/2011GL050099, 2012.

Zhang, H. and Ying, Q.: Secondary organic aerosol formation and source apportionment in southeast texas, Atmos. Environ., 45, 3217-3227, 2011.

Zhang, H., Lin, Y.-H., Zhang, Z., Zhang, X., Shaw, S. L., Knipping, E. M., Weber, R. J., Gold, A., Kamens, R. M., and Surratt, J. D.: Secondary organic aerosol formation from methacrolein photooxidation: roles of $\mathrm{NO}_{\mathrm{x}}$ level, relative humidity and aerosol acidity, Environ. Chem., 9, 247-262, doi.org/10.1071/EN12004, 2012.

Zhang, Q., Jimenez, J. L., Canagaratna, M. R., Allan, J. D., Coe, H., Ulbrich, I., Alfarra, M. R., Takami, A., Middlebrook, A. M., Sun, Y. L., Dzepina, K., Dunlea, E., Docherty, K., DeCarlo, P. F., Salcedo, D., Onasch, T., Jayne, J. T., Miyoshi, T., Shimono, A., Hatakeyama, S., Takegawa, N., Kondo, Y., Schneider, J., Drewnick, F., Borrmann, S., Weimer, S., Demerjian, K., Williams, P., Bower, K., Bahreini, R., Cottrell, L., Griffin, R. J., Rautiainen, J., Sun, J. Y., Zhang, Y. M., and Worsnop, D. R.: Ubiquity and dominance of oxygenated species in organic aerosols in anthropogenically influenced Northern Hemisphere midlatitudes, Geophys. Res. Lett., 34, L13801, doi:10.1029/2007GL029979, 2007. 